\title{
Estimasi Percampuran Turbulen di Laut Sulawesi menggunakan Thorpe Analisis
}

\author{
Hadi Hermansyah1*, Agus Saleh Atmadipoera², Tri Prartono², Indra Jaya², \\ Fadli Syamsudin ${ }^{3}$ \\ 'Politeknik Negeri Balikpapan \\ Jl. Soekarno Hatta KM. 8 Kota Balikpapan, Kalimantan Timur 76129 Indonesia \\ 2Departemen IImu dan Teknologi kelautan, Fakultas Perikanan dan IImu Kelautan, \\ Institut Pertanian Bogor \\ Jl. Agatis, Babakan, Kec. Dramaga, Bogor, Jawa Barat 16128 Indonesia \\ ${ }^{3}$ Badan Pengkajian dan Penerapan Teknologi (BPPT) Republik Indonesia \\ JI. KW Puspitek Setu Serpong Kota Tangerang Selatan, Banten, Indonesia \\ Email: hadi.hermansyah@poltekba.ac.id
}

\begin{abstract}
Turbulent Mixing in the Sulawesi Sea Using Thorpe Analysis Estimation

Dissipation of internal tides will cause mixing, The mixing process at sea plays a key role in controlling large-scale circulation and ocean energy distribution. The aim of this research was to estimate the vertical eddy diffusivity (turbulent mixing values) of water mass using Thorpe analysis. The results showed that the location where strong mixing occurred in the "near-field" area around Sangihe Island with vertical diffusivity value $K_{z} \sim 10^{-2} \mathrm{~m}^{2} \mathrm{~s}^{-1}$. Even in areas far-field(far from the generating site) are found vertical diffusivity $K_{z} \sim 10^{-4} \mathrm{~m}^{2} \mathrm{~s}^{-1}$, the impact of internal tides propagation dissipation. Based on the result of the observation, it shows that the level of kinetic energy of eddy turbulen dissipation $(\varepsilon)$ in the Sulawesi Sea on all layers has an average value of $3.03 \times 10^{-6} \mathrm{Wkg}^{-1}$. The value of $\varepsilon$ in the thermocline layer is greatest $\left(8.96 \times 10^{-6} \mathrm{~W} \mathrm{~kg}^{-1}\right)$ compared to the mixed surface layer and the almost homogeneous deep layer, the increase in mixing in the area near the ridge due to the closer water column to the base topography. The average turbulent rate of $1.01 \times 10^{-2} \mathrm{~m}^{2} \mathrm{~s}^{-1}$, the strongest fluctuation of value occurs in the thermocline layer, ranging from $1.94 \times 10^{-4}$ to $2.01 \times 10^{-1} \mathrm{~m}^{2} \mathrm{~s}^{-1}$ with an average of about $2.39 \times 10^{-2} \mathrm{~m}^{2} \mathrm{~s}^{-1}$. The value of this turbulent mixing is higher than the previous measurements in some Indonesian ocean. This is allegedly due to the existence of a strong internal tidal energy and its interaction with topography in the Sulawesi Sea.
\end{abstract}

Keywords: turbulent mixing, Thorpe analysis, diffusivity, Dissipation, Sulawesi Sea

\begin{abstract}
Abstrak
Disipasi dari pasang surut internal menjadi faktor utama terjadinya proses percampuran di laut, proses percampuran di laut memainkan peran kunci dalam mengendalikan sirkulasi skala besar dan distribusi energi lautan. Penelitian ini bertujuan untuk mengestimasi nilai difusivitas eddy vertikal massa air dengan analisis Thorpe. Berdasarkan hasil penelitian ini dapat ditunjukkan bahwa percampuran yang kuat terjadi di area sekitar Pulau Sangihe-Talaud dengan nilai difusivitas vertikal $\mathrm{K}_{\mathrm{z}} \sim 10^{-2} \mathrm{~m}^{2} \mathrm{~s}^{-1}$. Bahkan pada area yang jauh dari pusat pembangkitan ditemukan difusivitas vertikal $\mathrm{K}_{\mathrm{z}} \sim 10^{-4} \mathrm{~m}^{2} \mathrm{~s}^{-1}$, hasil disipasi propagasi pasang surut internal. Berdasarkan hasil pengamatan dapat ditunjukkan bahwa rata-rata tingkat energi kinetik disipasi turbulen eddy $(\varepsilon)$ di Laut Sulawesi adalah $3.03 \times 10^{-6} \mathrm{~W} \mathrm{~kg}^{-1}$. Nilai $\varepsilon$ pada lapisan termoklin lebih tinggi $\left(8.96 \times 10^{-6} \mathrm{Wkg}^{-1}\right)$ jika dibandingkan dengan lapisan permukaan maupun lapisan dalam, percampuran di daerah sekitar ridge mengalami peningkatan kemungkinan disebabkan kolom air mendekati area topografi atau dasar perairan. Rata-rata nilai percampuran turbulen di Laut Sulawesi adalah sebesar $1.01 \times$
\end{abstract}


$10^{-2} \mathrm{~m}^{2} \mathrm{~s}^{-1}$, fluktuasi paling kuat terjadi pada lapisan termoklin, yang berkisar antara $1.94 \times 10^{-4}$ sampai $2.01 \times 10^{-1} \mathrm{~m}^{2} \mathrm{~s}^{-1}$ dengan rerata sekitar $2.39 \times 10^{-2} \mathrm{~m}^{2} \mathrm{~s}^{-1}$. Adanya interaksi yang kuat antara energi pasang surut internal dengan area topografi dasar perairan inilah yang menjadikan Laut Sulawesi memilik nilai percampuran turbulen yang lebih tinggi jika dibandingkan dengan pengukuran sebelumnya di beberapa perairan Indonesia yang lain.

Kata Kunci: Percampuran Turbulen, Thorpe Analisis, Difusivitas, disipasi, Laut Sulawesi

\section{PENDAHULUAN}

Massa air dapat berubah karakternya karena adanya proses pencampuran (mixing) di laut, selain itu vertical mixing juga dapat mempengaruhi gerakan massa air dari kolom air lapisan dasar perairan yang kaya kandungan nutrien sehingga mampu mensuplai nutrien menuju lapisan permukaan (Law et al., 2003). Pada saat melewati Arlindo, karakteristik massa air yang bergerak dari laut Pasifik menuju laut Hindia mengalami perubahan. Berdasarkan hasil penelitian sebelumnya bahwa salinitas dari massa air tersebut mengalami perubahan karakteristik, yaitu salinitas massa air North Pasific South Water dan North Pasific Intermediate Water masing-masing berubah dari 34,90 psu dan 34,35 psu berubah menjadi 34,54 psu dan 34,47 psu. Berubahnya salinitas dari massa air ini mengindikasikan kuatnya proses vertical mixing yang terjadi di perairan laut Indonesia (Atmadipoera et al., 2009; Hermansyah et al., 2019).

Laut Indonesia adalah perairan yang diindikasikan memiliki pasang surut internal yang kuat. Berdasarkan penelitian yang dilakukan oleh Carrere \& Lyard (2003) menunjukkan bahwa energi pasang surut barotropik yang di transferkan menjadi pasang surut baroklinik adalah sebesar 0,11 TW atau $10 \%$ dari total transfer energi di seluruh lautan. Kuatnya pasang surut internal menjadi energi utama atau proses inti yang berperan dalam merubah massa air arus lintas Indonesia menuju Samudera Hindia. Laut Sulawesi merupakan salah satu wilayah laut di Indonesia dengan nilai pasang surut baroklinik yang tinggi, kecepatan arus pasang surut internal di lokasi ini yaitu lebih dari $3.0 \mathrm{~ms}^{-1}$ (Jackson, 2007). Potensi percampuran turbulen terjadi di Laut Sulawesi sangat besar karena adanya keterkaitan antara energi dengan kecepatan arus pasang surut internal yang tinggi.
Perbedaan densitas yang digambarkan oleh kondisi temperatur, salinitas, dan kedalaman dapat mengakibatkan terjadinya Percampuran massa air. Korelasi antara temperatur dan salinitas di suatu perairan dapat menjadi acuan dalam mengamati asal-usul, penyebarannya, terbentuknya pelapisan, dan proses percampuran massa air secara temporal dan spasial. Pecahnya (breaking) gelombang internal merupakan salah satu pemicu terjadinya turbulen dalam fluida. Lane-Serff (2004) menjelaskan bahwa gambaran dari topografi di wilayah ambang (sill) memberi dampak penting pada karakteristik aliran dan percampuran massa air. Hal ini akan mengakibatkan adanya aliran massa air yang mengalir terbatas oleh luasan atau kedalaman selat, sehingga tekanan dari arus lebih tinggi jika dibandingkan dengan laut terbuka. Kondisi ini akan memicu terpecahnya gelombang akibat terjadinya gesekan antara gelombang internal dengan lapisan (topografi) dasar perairan (Polzin et al., 1997). Fenomena gelombang internal yang terhalang pada area sill menyebabkan wilayah ini memiliki energi pasang surut internal yang tinggi, sehingga massa air dari Arlindo akan melewati beberapa hambatan topografi perairan berupa sill seperti pada beberapa selat (Ffield \& Gordon, 1992; Ffield, 1994).

Percampuran massa air di laut Indonesia terjadi akibat adanya pasang surut internal. Ffield \& Gordon (1992) menghitung nilai percampuran turbulen pada lapisan termoklin di perairan Indonesia dan nilai yang diperoleh adalah $1.0 \times 10^{-4} \mathrm{~m}^{2} / \mathrm{s}$. Nilai tersebut mendekati dengan hasil yang dilakukan oleh Koch-Larrouy et al. (2007) di perairan Indonesia yaitu sebesar $1.5 \times 10^{-4} \mathrm{~m}^{2} / \mathrm{s}$. Kajian selanjutnya dengan pemodelan numerik juga dilakukan oleh Nagai et al. (2015) dan menghasilkan nilai vertikal difusivitas di Perairan Indonesia sebesar $\sim 10^{-2} \mathrm{~m}^{2} / \mathrm{s}$ di 
daerah pusat pembangkitan, dan pada daerah yang jauh dari pusat pembangkitan menurun $\sim 10^{-4} \mathrm{~m}^{2} / \mathrm{s}$. Hermansyah et al. (2019) dalam penelitiannya juga menghitung distribusi difusivitas vertikal dengan menggunakan model numerik ROMS, pada lokasi dimana terjadi percampuran yang kuat terjadi di area sekitar pulau Sangihe dengan nilai difusivitas vertical $\mathrm{K}_{\mathrm{V}} \sim 10^{-2} \mathrm{~m}^{2} \mathrm{~s}^{-1}$, bahkan pada area yang jauh dari pusat pembangkitan ditemukan difusivitas vertikal $\mathrm{K}_{\mathrm{V}} \sim 10^{-4} \mathrm{~m}^{2} \mathrm{~s}^{-1}$, hasil disipasi propagasi pasang surut internal. Beberapa hasil kajian tersebut masih berupa model dan belum ada yang melakukan eksperimen lapangan di wilayah Laut Sulawesi. Hal ini yang menjadi salah satu sebab pentingnya dilakukan penelitian percampuran turbulen di Perairan Laut Sulawesi. Kawasan ini memiliki topografi dasar laut yang kompleks, serta menunjukkan transfer energi pasang surut barotropik ke baroklinik yang kuat diduga sebagai pembangkit percampuran turbulen (Nagai et al., 2015).

\section{MATERI DAN METODE}

Sumber Data menggunakan data sekunder yang diperoleh dari Pusat Penelitian dan Pengembangan Geologi Kelautan (P3GL) yang diambil pada ekspedisi pelayaran Cruise Tanggal 14-21 Mei 2006. Alat yang digunakan adalah Conductivity Temperature Depth (CTD) Sea-Bird Electronics (SBE) 911 Plus untuk mengukur data temperatur, salinitas, dan tekanan.

Penentuan Lapisan Kolom AirKolom air dibagi menjadi 3 lapisan, yaitu tercampur, termoklin, dan homogen di bagian dasar perairan (lapisan dalam). Gradien densitas $\left(\sigma_{\theta}\right)$ kolom perairan menjadi dasar dalam pengelompokan lapisan ini. Lorbacher et.al. (2005) menjelaskan bahwa gradient densitas $\sigma_{\theta}$ lebih realistis untuk dijadikan sebagai dasar pembagian lapisan kolom air dibandingkan dengan temperatur, karena stratifikasi vertikal yang tepat tidak selalu bisa dihasilkan dari profil temperatur. Penentuan Lapisan tercampur dihitung menggunakan gradient 0,02 dengan densitas permukaan sebagai titik acuan. Jika gradient $\sigma_{\theta}$ lebih besar dari 0,02, maka dapat dikategorikan lapisan tersebut merupakan lapisan termoklin (Cisewski et al., 2005). Pengamatan data densitas secara visual dapat dilakukan untuk menentukan batasan antara lapisan termoklin dengan lapisan dalam yang selanjutnya dicrossceck menggunakan data temperatur, area dimana nilai densitas tidak mengalami penurunan secara tajam terhadap kedalaman merupakan batas kedua lapisan.

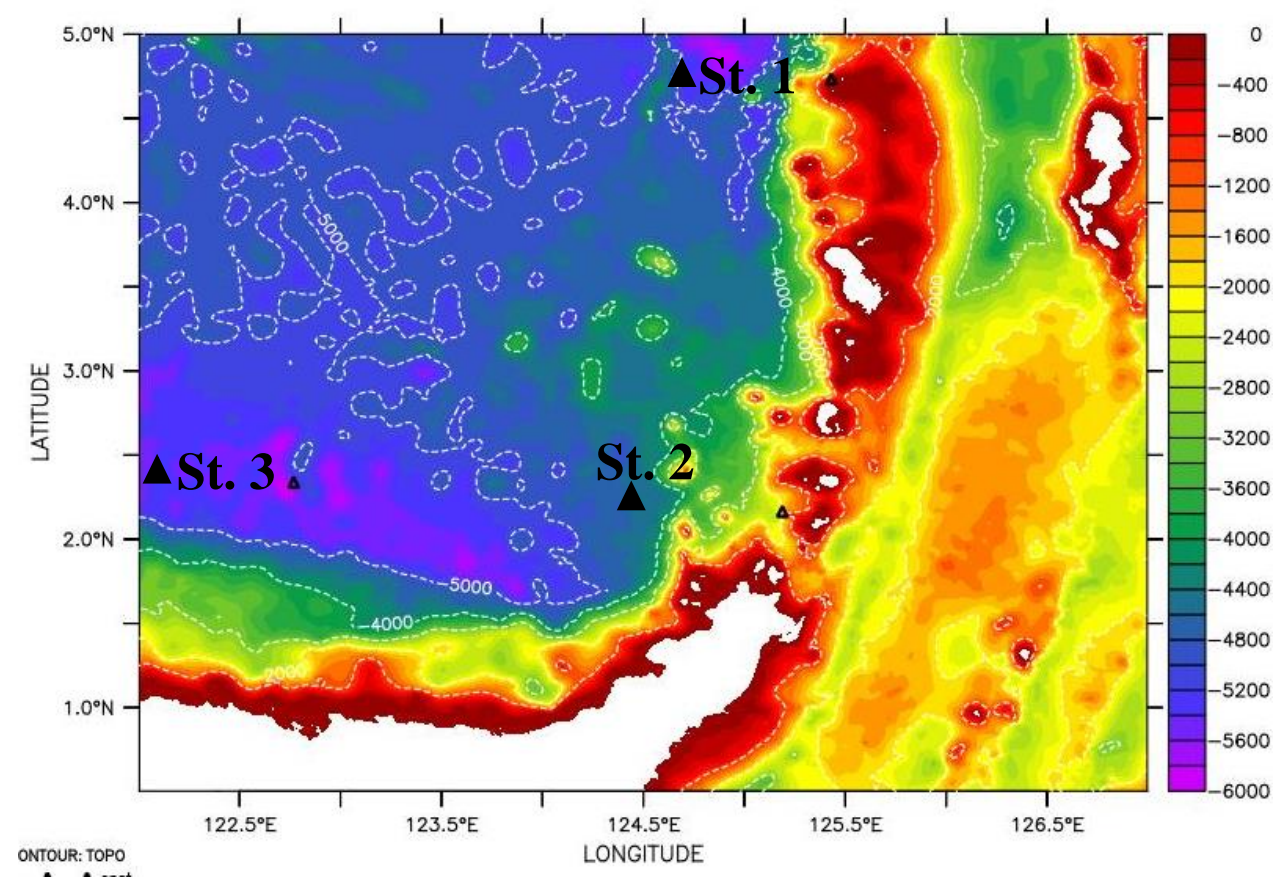

Gambar 1. Batimetri Laut Sulawesi dengan tiga Stasiun CTD dari arsip data P3GL 
Analisis Data Dalam penelitian ini pengolahan data menggunakan Ocean Data View (ODV) 4.1.3, Microsoft Excell0, dan Matlab versi 7.11.1 (R2010bSP1). Tahap awal analisis data adalah menentukan nilai Thorpe displacement, panjang skalaozmidov, frekuensi Brunt Väisälä, skala Thorpe, dan tingkat energi kinetik disipasi turbulen eddy, selanjutnya berdasarkan nilai parameter tersebut dapat diestimasi nilai difusivitas vertikal eddy. Tahapan yang dilakukan adalah penyusunan kembali profil densitas yang diperoleh dari data CTD ke dalam kondisi stabilitas statis. Nilai densitas yang digunakan dalam menentukan Frekuensi Brunt Väisälä diperoleh dari profil densitas yang telah dilakukan penyusunan dalam bentuk stabilitas statis, sehingga nilai yang diperoleh nilainya selalu positif.

Nilai difusivitas vertikal eddy $\left(K_{z}\right)$ dapat diestimasi menggunakan skala Thorpe, $L_{T}$ yang didefinisikan sebagai skala panjang overturn vertical turbulen dalam aliran yang terstratifikasi. Overturn dapat diamati dari nilai 'inversi' densitas, dimana gradient densitas tidak stabil pada kondisi gravitasi (Galbraith \& Kelley, 1996). Selanjutnya, untuk memperoleh nilai densitas potensial $\left(\sigma_{\theta}\right)$ yang stabil, inversi dari nilai densitas tersebut diurutkan kembali (reorder), sehingga tahap ini bisa mengantisipasi kemungkinan terjadinya overlap dari nilai densitas yang telah diurutkan.

\section{HASIL DAN PEMBAHASAN}

Lapisan Kolom Perairan Profil massa air perairan Laut Sulawesi mulai dari lapisan permukaan sampai lapisan dasar dapat dilihat dengan pada Gambar 2. Gradient densitas $\left(\Delta \sigma_{\theta}\right)$ dan temperatur $(\Delta T)$ dapat dijadikan parameter utama dalam menentukan lapisan perairan (Thomson \& Fine, 2002; Montegut et al., 2004). Jika $\Delta T<0,1^{\circ} \mathrm{C}$ dan $\Delta \sigma_{\theta}<0,02 \mathrm{~kg} \mathrm{~m}^{-3}$ maka kolom perairan tersebut dapat dikelompokkan sebagai lapisan tercampur (permukaan), sedangkan lapisan termoklin diperoleh dengan menggunakan nilai $\Delta T \geq 0.1^{\circ} \mathrm{C}$ dan $\Delta \sigma_{\theta} \geq 0,02 \mathrm{~kg} \mathrm{~m}^{-3}$ (Kara et al., 2000; Cisewski et al., 2005). Selanjutnya, pengamatan secara visual pada data densitas maupun temperatur dapat dilakukan untuk menentukan lapisan dalam dimana pada lapisan kolom air ini temperatur dan densitas tidak mengalami penurunan secara signifikan terhadap kedalaman.

Lapisan dengan nilai temperatur hampir seragam dan paling tinggi dikelompokkan sebagai Lapisan permukaan (tercampur). Kedalaman lapisan ini di Laut Sulawesi berkisar antara $0 \mathrm{~m}$ sampai $25-35 \mathrm{~m}$. Ketebalan lapisan paling besar diperoleh pada stasiun 2 dan paling tipis didapatkan pada stasiun 1. Intensitas gelombang internal yang terjadi di area tersebut diduga menjadi faktor utama terjadinya perbedaan ketebalan kedua lapisan ini. Pada kondisi gelombang internal mencapai puncak dan melewati kolom perairan maka lapisan permukaan akan termampatkan dan lapisan akan berubah menjadi lebih tipis, namun jika kolom perairan dilewati oleh lembah gelombang internal maka lapisan permukaan akan menjadi lebih tebal. Hal ini sesuai dengan penjelasan Li et al. (2000) yang menyatakan bahwa faktor utama dalam menentukan perbedaan tingkat ketebalan lapisan permukaan adalah diakibatkan adanya gelombang internal dan kecepatan tiupan angin.

Lapisan termoklin di Laut Sulawesi juga secara rata-rata mengalami penurunan temperatur $\geq 0.1^{\circ} \mathrm{C}$ per satu meter. Kedalaman batas atas pada lapisan termoklin berkisar antara 25-35 $\mathrm{m}$ dan kedalaman batas bawah antara 250-350 m. Aktivitas gelombang internal diduga menyebabkan terjadinya perbedaan kedalaman batas lapisan ini, dimana puncak atau lembah gelombang internal yang melewati kolom perairan sangat mempengaruhi posisi lapisan atas termoklin akan lebih dangkal atau dalam. Lapisan dalam yang homogen di Laut Sulawesi memiliki kedalaman batas atas antara 350 $250 \mathrm{~m}$ dan kedalaman batas bawah antara $444-1008 \mathrm{~m}$.

Stabilitas Statis Hasil analisis frekuensi Brunt Väisälä $\left(N^{2}\right)$ untuk pengukuran CTD di Laut Sulawesi ditunjukkan pada Gambar 3. Hasil analisa menunjukkan bahwa rata-rata tingkat kestabilan massa air pada lapisan permukaan tercampur cenderung rendah 


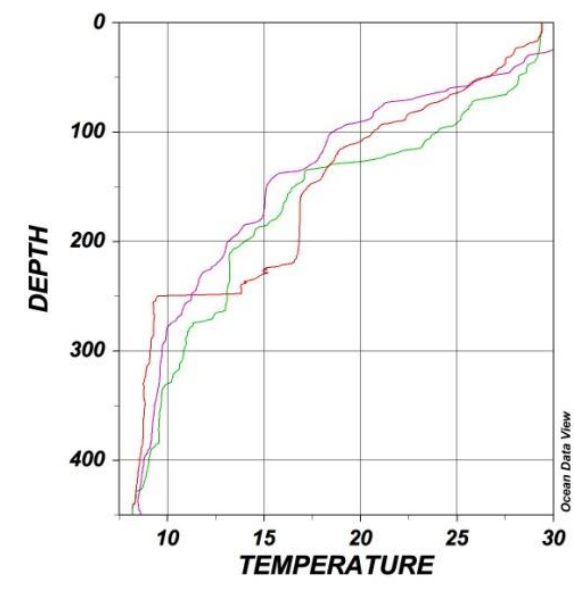

(a)

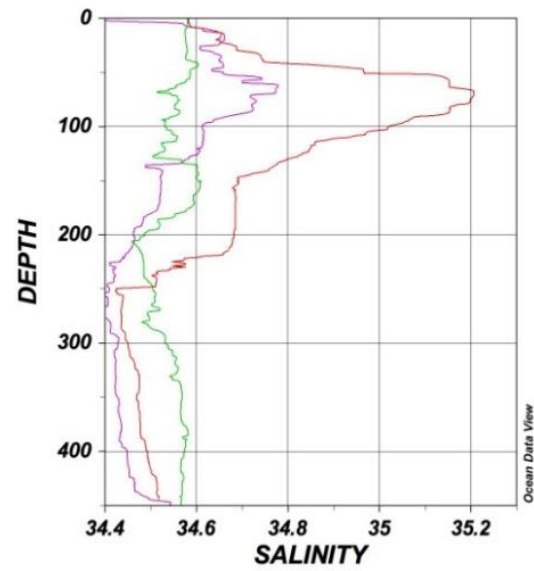

(b)

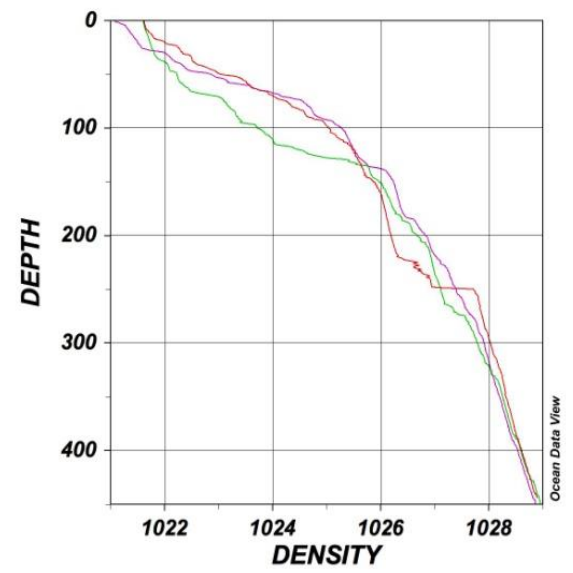

(c)

Gambar 2. Profil vertikal temperatur (a), salinitas (b), dan densitas (c) yang diperbesar sampai tekanan $450 \mathrm{db}$.

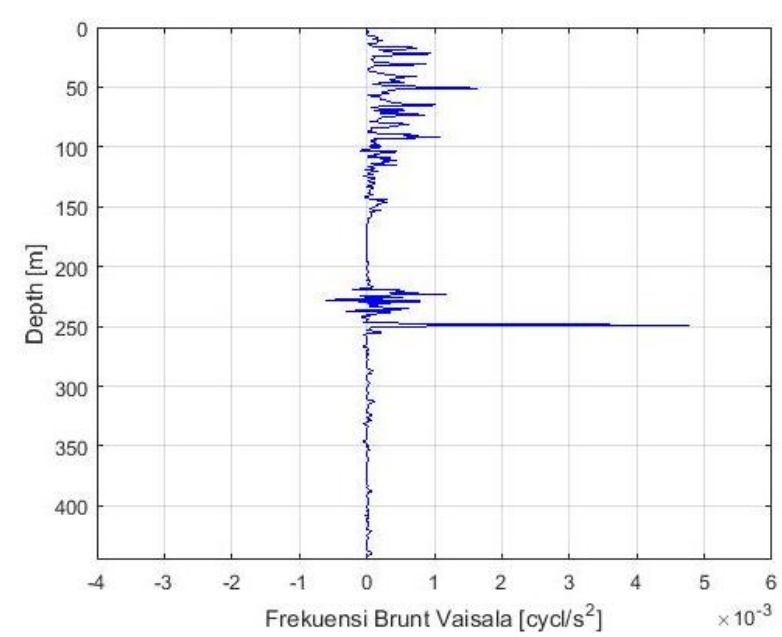

Stasiun 1

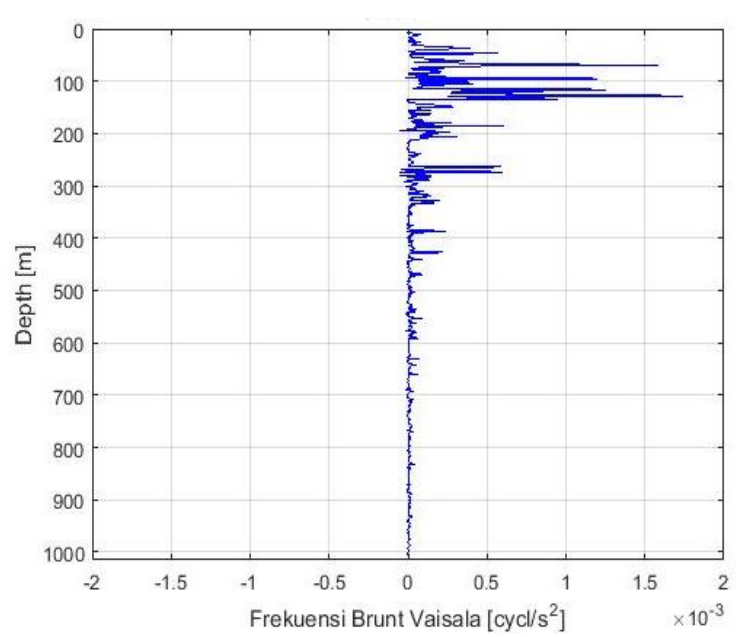

Stasiun 2

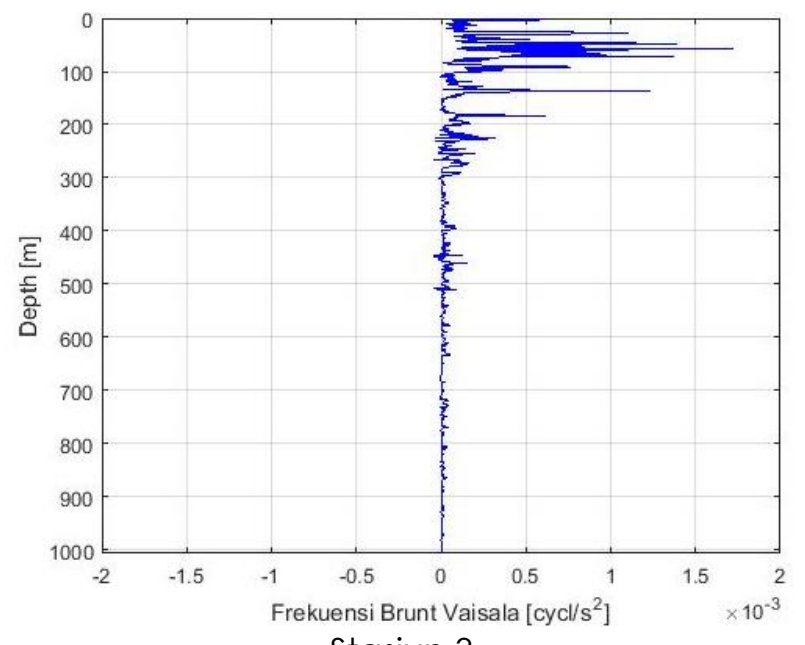

Stasiun 3

Gambar 3. Frekuensi Brunt Vaisala 
$\left(1,31 \times 10^{-4} \mathrm{~s}^{-1}\right)$, nilai frekuensi tinggi terlihat di lapisan termoklin (rata-ratal,72 $\left.\times 10^{-4} \mathrm{~s}^{-1}\right)$ dan rendah kembali dilapisan dalam (rata-rata $\left.1,18 \times 10^{-5} 5^{-1}\right)$, terjadinya fluktuasi nilai frekuensi tersebut sangat ditentukan oleh gradient temperatur dan salinitas.

Gradient densitas terlihat tidak terlalu tinggi baik pada lapisan permukaan maupun lapisan dalam. Pond dan Pickard (1983) menjelaskan bahwa adanya lapisan pycnocline menjadi pemicu utama tingginya nilai gradient densitas di lapisan termoklin. Lebih lanjut Pond dan Pickard (1983) menjelaskan juga bahwa kondisi stabilitas statis pada suatu lapisan akan semakin besar jika nilai $N^{2}$ pada lapisan tersebut semakin tinggi, sebaliknya kondisi ketidakstabilan kolom perairan atau instabilitas statis terjadi jika nilai $N^{2}$ semakin negatif. Sehingga, hal ini dapat diindikasikan bahwa lapisan yang paling stabil adalah lapisan termoklin jika dibandingkan dengan lapisan permukaan maupun lapisan dalam.

Ada hal menarik terjadi pada stasiun 1 , nilai $\mathrm{N}^{2}$ justru rendah pada lapisan termoklin, dengan kata lain kestabilan pada lapisan termoklin paling rendah yang diindikasikan dengan banyaknya nilai frekuensi yang bernilai negatif seperti terlihat pada Gambar 3a. Pada Iapisan termoklin, terlihat bahwa massa air dalam kondisi instabilitas statis mendominasi di Stasiun 1 (220-250 db) dibandingkan dengan massa air pada stasiun lain. Profil vertikal temperatur, salinitas, dan densitas memberikan pengaruh yang kuat terhadap Kondisi instabilitas massa air ini, dimana pada lapisan termoklin stasiun 1 profil vertikal massa air terlihat tidak beraturan dan berbentuk zigzag (Gambar 2). Kondisi ini diduga terjadi akibat adanya proses pengadukan pada lapisan termoklin karena adanya intensitas gelombang internal yang sangat kuat pada lapisan tersebut.

Estimasi Skala ThorpeHasil pengamatan memperlihatkan profil menegak densitas Laut Sulawesi diidentifikasi melalui data kondisi instabilitas statis (Gambar 3), proses displacement memungkinkan terjadi pada perairan ini. Pada Gambar 4b dapat diamati bahwa massa air dengan densitas yang lebih tinggi berada di atas massa air yang berdensitas rendah. Berdasarkan Gambar 4 dapat ditunjukkan juga bahwa densitas awal (garis merah) massa air dapat di-reorder ke kondisi densitas stabilitas statis (garis biru), sehingga massa air dapat berubah kondisinya dari posisi awal ke posisi yang baru. Tanda panah adalah arah relokasi massa air menuju posisi yang stabil, jarak perpindahan massa air ke posisi baru tersebut akan menghasilkan Thorpe displacement.

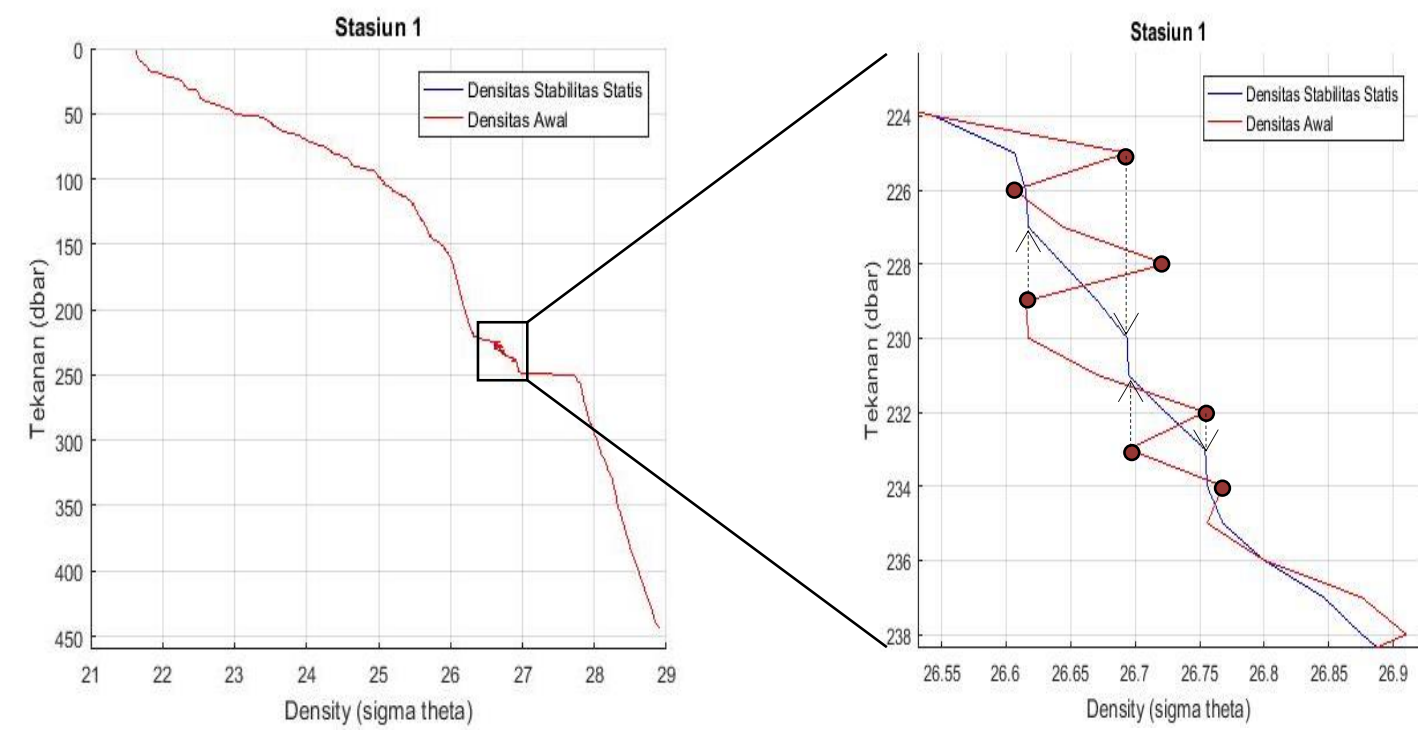

Gambar 4. Perbandingan densitas awal hasil pengukuran (merah) dengan densitas stabilitas statis setelah disusun ulang (biru) di Stasiun 1 (a), Perbesaran area kotak pada gambar a (b). 

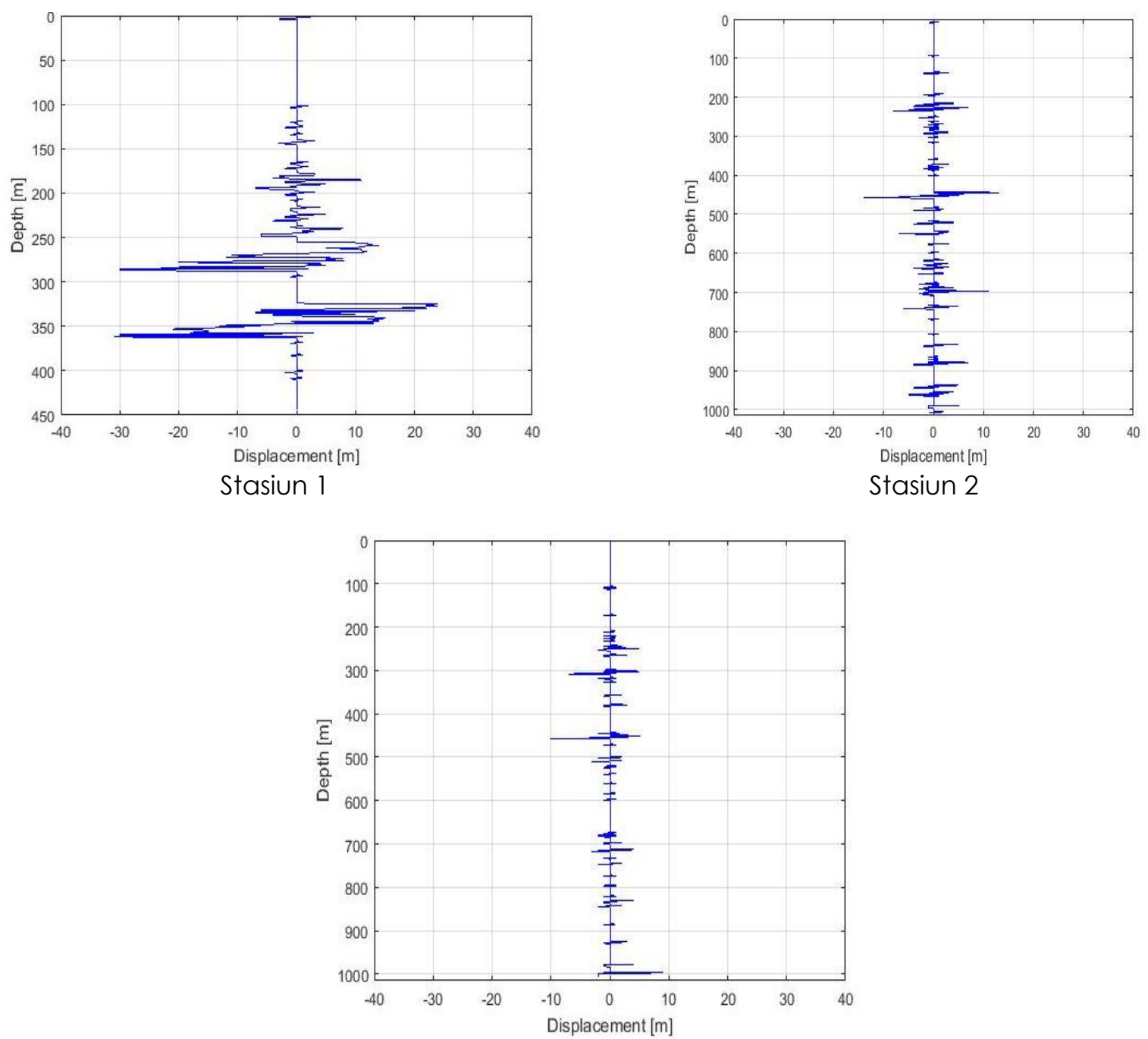

Stasiun 3

Gambar 5. Profil perpindahan Thorpe (d)

Profil nilai perpindahan Thorpe untuk tiga data stasiun CTD Laut Sulawesi diperlihatkan pada Gambar 5. Massa air akan bergerak menuju ke arah atas untuk mendapatkan posisi kestabilan statis, kondisi ini ditunjukkan oleh nilai positif, posisi ini terjadi bila massa air yang memiliki densitas lebih rendah berada di bawah massa air yang densitasnya tinggi

Pada area sekitar Kepulauan SangiheTalaud (Stasiun 1), nilai perpindahan Thorpe pada lapisan permukaan berkisar antara -3 sampai 3. Nilai perpindahan Thorpe pada lapisan termoklin terjadi pada kisaran -7 sampai $11 \mathrm{~m}$. Sedangkan pada lapisan dalam nilai perpindahan Thorpe berada pada kisaran -31 sampai $24 \mathrm{~m}$. Hasil tersebut memperlihatkan bahwa nilai perpindahan Thorpe pada lapisan dalam lebih tinggi bila dibandingkan dengan lapisan permukaan maupun lapisan termoklin, nilai stabilitas massa air yang rendah pada lapisan ini menjadi penyebab utama terjadinya kondisi tersebut.

Pada area bagian selatan Kepualavan Sangihe-Talaud (Stasiun 2), perpindahan nilai d pada lapisan permukaan juga terdeteksi dari -1 sampai 1. Sementara nilai $d$ pada lapisan termoklin terdeteksi berkisar $-8 \mathrm{~m}$ sampai $7 \mathrm{~m}$. Pada lapisan homogen (lapisan dalam), nilai $d$ untuk Stasiun 2 berada pada kisaran -14 sampai $13 \mathrm{~m}$. Pada area basin Laut Sulawesi (Stasiun 3), nilai d pada lapisan permukaan tidak terdeteksi. Pada lapisan 
termoklin, nilai $d$ berada pada kisaran -2 sampai $5 \mathrm{~m}$ dan bagian dalam terdeteksi - 10 sampai $9 \mathrm{~m}$.

Secara keseluruhan nilai displacement untuk tiga stasiun CTD di Laut Sulawesi menunjukkan nilai yang rendah pada lapisan tercampur, hal ini diduga karena pengaruh kecepatan tiupan angin yang sangat kecil dan juga adanya sistem pencahayaan yang cukup tinggi. Selain itu, pada lapisan termoklin diperoleh nilai displacement juga rendah. Rendahnya nilai displacement pada lapisan termoklin kemungkinan terjadi karena lapisan ini adalah lapisan dengan nilai stabilitas statis paling besar.

Nilai d yang paling tinggi diidentifikasi terjadi pada lapisan dalam, tingginya nilai $d$ pada lapisan ini kemungkinan karena nilai stabilitas statis yang relatif lebih rendah bila dibandingkan dengan nilai stabilitas statis pada lapisan termoklin (Gambar 3). Dapat dijelaskan juga melalui Gambar 5 bahwa nilai displacement yang paling tinggi berada pada stasiun 1 dibandingkan dengan stasiun lainnya. Hal ini terjadi kemungkinan adanya efek dari aktivitas pembangkitan gelombang internal akibat adanya interaksi antara arus pasang dengan ambang Sangihe-Talaud, sehingga hal tersebut menimbulkan adanya proses adukan yang menyebabkan rendahnya kestabilan massa air pada stasiun ini. Hal ini diperkuat oleh Polzin et al. (1997) bahwa tingginya nilai displacement di dasar perairan diakibatkan oleh adanya gesekan antara dasar topografi dengan arus yang melintas di atasnya.

Energi Kinetik Disipasi Turbulen( $\boldsymbol{\varepsilon}$ )Estimasi rata-rata nilai energi kinetik disipasi turbulen eddy $(\varepsilon)$ Laut Sulawesi pada seluruh lapisan adalah $1,17 \times 10^{-6} \mathrm{Wkg}^{-1}$, sedangkan untuk nilai profil energi kinetik turbulen dan difusivitas vertikal pada setiap lapisan disajikan pada Gambar 6. Terlihat bahwa nilai $\varepsilon$ pada lapisan termoklin paling tinggi $\left(8,96 \times 10^{-6} \mathrm{Wkg}^{-1}\right)$ dibandingkan dengan lapisan lain, hal ini diakibatkan karena tingginya nilai $d$ dan $L_{T}$ yang memiliki korelasi linier dengan nilai $\varepsilon$. Hal ini sesuai dengan penjelasan Finnigan et al. (2002) bahwa percampuran di daerah sekitar ridge akan mengalami peningkatan disebabkan karena rapatnya kolom perairan dengan dasar topografi.
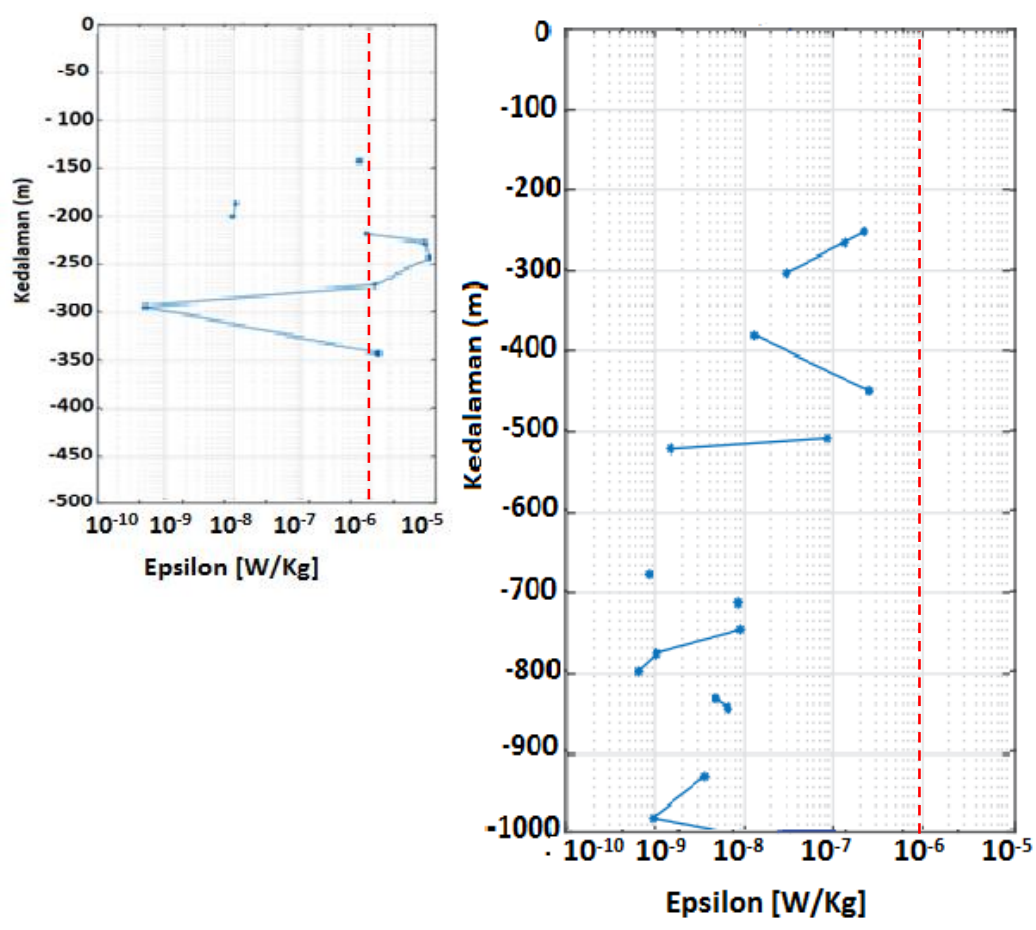

Stasiun 1

Stasiun 3

Gambar 6. Perbandingan nilai energi kinetik disipasi turbulen Stasiun 1 dan 3 
Berdasarkan Gambar 6 terlihat bahwa nilai percampuran turbulen pada area pembangkitan gelombang internal cukup tinggi. Pada stasiun 1 daerah yang mewakili area sekitar Sangihe-Talaud, nilai Energi Kinetik Disipasi Turbulen mencapai lebih dari $10^{-6} \mathrm{~W} / \mathrm{Kg}$, sedangkan pada stasiun 3 yang mewakili area sekitar basin Laut Sulawesi dan juga merupakan area yang jauh dari pusat pembangkitan gelombang internal nilai energi disipasi yang terjadi sangat lemah dan nilainya jauh lebih kecil dari $10^{-6} \mathrm{~W} / \mathrm{Kg}$. Hal ini mengindikasikan bahwa kuatnya nilai energi kinetik disipasi turbulen di daerah yang memiliki sill terjadi akibat dekatnya kolom air dengan lapisan dasar topografi, dan dalam proses percampuran terdapat sejumlah energi kinetik turbulen yang dilepaskan untuk memodifikasi struktur massa air.

Lebih lanjut dapat diidentifikasi bahwa adanya disipasi energi kinetik turbulen eddy yang kuat pada area dasar topografi menunjukkan bahwa energi yang dilepaskan intensitasnya meningkat terjadi pada lapisan dasar perairan dan pada area sekitar sill. Nilai energi kinetik disipasi turbulen yang diperoleh di Laut Sulawesi secara keseluruhan termasuk kategori cukup tinggi dan tidak jauh berbeda dengan nilai energi kinetik disipasi turbulen yang diperoleh di beberapa lokasi pembangkitan gelombang internal di wilayah perairan Indonesia, sebagaimana hasil $\varepsilon$ di Selat Ombai yang diperoleh Suteja et al. (2012) mencapai $4,22 \times 10^{-6} \mathrm{Wkg}^{-1}$, di Dewakang sill nilai $\varepsilon$ mencapai $8.35 \times 10$ ${ }^{7}$ sampai $4.37 \times 10-6 \mathrm{Wkg}^{-1}$, dan di Perairan Selat Alor rata-rata nilai energi kinetik turubulen mencapai $1.08 \times 10^{-6} \mathrm{Wkg}^{-1}$ (Purwandana et al., 2014).

\section{Difusivitas Vertikal Eddy $\left(K_{z}\right)$}

Perbandingan nilai difusivitas vertikal eddy $\left(K_{z}\right)$ pada stasiun 1 yang mewakili area Sangihe-Talaud dan Stasiun 3 yang mewakili area basin Laut Sulawesi disajikan pada Gambar 7.

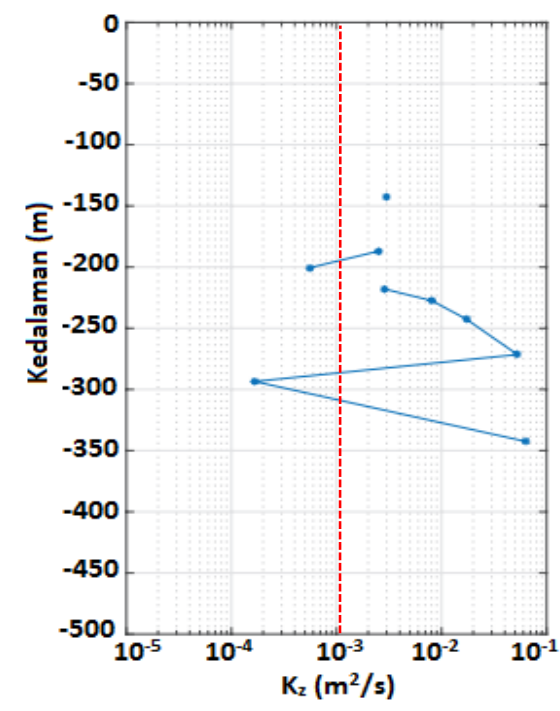

Stasiun 1

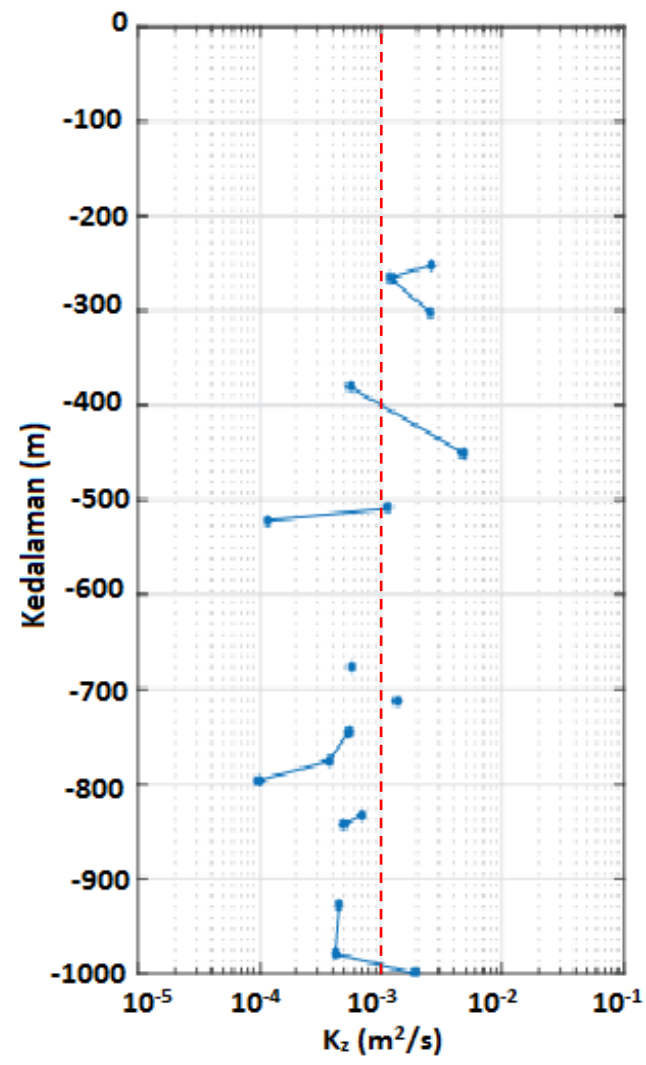

Stasiun 3

Gambar 7. Profil difusivitas vertikal eddy $\left(K_{z}\right)$ pada stasiun 1 dan 3 
Tabel 1. Distribusi nilai rata-rata difusivitas vertikal eddy $\left(K_{z}\right)$

\begin{tabular}{lcc}
\hline Lapisan & Rata-rata $K_{Z}\left(\mathrm{~m}^{2} \mathrm{~s}^{-1}\right)$ & Standar Deviasi \\
\hline Tercampur & $6.96 \mathrm{E}-04$ & $\pm 3.90 \mathrm{E}-04$ \\
Termoklin & $2.39 \mathrm{E}-02$ & $\pm 7.72 \mathrm{E}-03$ \\
Dalam & $8.51 \mathrm{E}-03$ & $\pm 8.08 \mathrm{E}-03$ \\
\hline
\end{tabular}

Disipasi yang tinggi dari energi kinetik turbulen pada area Sangihe-Talaud di Perairan Laut Sulawesi mengindikasikan terjadinya percampuran vertikal massa air yang kuat pada area tersebut. Nilai $K_{z}$ yang tertinggi terjadi pada lapisan termoklin, berkisar antara $1,96 \times 10^{-4}$ sampai $2,00 \times 10^{-1} \mathrm{~m}^{2} \mathrm{~s}^{-}$ 1 dengan rerata sekitar $2,39 \times 10^{-2} \mathrm{~m}^{2} \mathrm{~s}^{-1}$, dan nilai tersebut lebih besar dibandingkan nilai $K_{\mathbf{z}}$ yang diperoleh Hatayama (2004) di sill Dewakang yang mencapai $6,0 \times 10^{-3} \mathrm{~m}^{2} \mathrm{~s}^{-1}$, sementara hasil yang diperoleh Purwandana et al. (2014) di Perairan Selat Alor rata-rata nilai $\left(K_{z}\right)$ mencapai $1.0 \times 10^{-3} \mathrm{~m}^{2} \mathrm{~s}^{-1}$. Lebih lanjut Hatayama (2004) menjelaskan bahwa tingginya nilai $K_{z}$ di sill Dewakang diakibatkan karena adanya arus semidiurnal $\left(M_{2}\right)$ yang sangat intensif.

Berdasarkan Gambar 7 dapat dilihat bahwa nilai $K_{z}$ pada area sekitar SangiheTalaud yang diwakili oleh stasiun 1 mencapai $1^{-1} \mathrm{~m}^{2} \mathrm{~s}^{-1}$, nilai tersebut jaun lebih tinggi dibandingkan dengan nilai $K_{z}$ pada wilayah basin Laut Sulawesi. Nilai difusivitas yang tinggi pada lapisan dasar dan area sekitar sill mengindikasikan bahwa nilai difusivitas vertikal ini kemungkinan dipengaruhi oleh turbulensi karena adanya interaksi antara pasang surut internal dengan topografi dasar yang mendangkal serta sill. Hermansyah et al. (2018) menjelaskan adanya keterkaitan antara gesekan dasar atau pembangkitan pasang surut internal dengan disipasi pasang surut. Terjadi peningkatan distribusi disipasi energi baroklinik yang sangat signifikan pada area dekat Kepulauan Sangihe-Talaud, area di mana terdapat sill.

Proses mixing (percampuran) yang terjadi khususnya pada daerah Kepulauan Sangihe-Talaud sangat dipengaruhi oleh hasil disipasi dari energi pasang surut barotropik dan baroklinik, dimana percampuran akibat adanya disipasi yang terjadi tepat di atas area slope topografi. Pola distribusi tingkat disipasi seperti ini mirip dengan hasil yang didapat oleh Finnigan et al. (2002) dan Hatayama et al. (2004). Aliran energi baroklinik yang kuat berasal dari area sekitar Kepulauan Sangihe-Talaud, yaitu lebih tinggi dari $10 \mathrm{~kW} / \mathrm{m}$, area tersebut juga diidentifikasi terjadinya konversi energi barotropik ke baroklinik yang kuat (Hermansyah et al., 2019). Nilai difusivitas vertikal eddy $\left(K_{z}\right)$ untuk lapisan massa air dari profil CTD di Laut Sulawesi disajikan pada Tabel 1.

Nilai rata-rata difusivitas vertikal eddy $\left(K_{z}\right)$ di Laut Sulawesi adalah $1.07 \times 10-2 \mathrm{~m}^{2} \mathrm{~s}^{-1}$, nilai tersebut lebih tinggi dari rata-rata difusivitas vertikal untuk perairan umum Indonesia seperti yang diperoleh KochLarrouy et al. (2007) yaitu sebesar 1,5 x 10-4 $\mathrm{m}^{2} \mathrm{~s}$ 1. Diduga tingginya nilai difusivitas vertikal di Laut Sulawesi ini sangat dipengaruhi oleh intensitas gelombang internal yang kuat terjadi di area ini. Hal ini dijelaskan oleh Nagai et al.(2015) bahwa Laut Sulawesi merupakan daerah yang memiliki pasang surut internal yang paling kuat di perairan Indonesia dan wilayah Sangihe-Talaud merupakan area pembangkit pasang surut baroklinik.

\section{KESIMPULAN}

Nilai difusivitas vertikal eddy di Laut Sulawesi secara keseluruhan lebih besar dibandingkan dengan perairan lainnya di Indonesia, hal ini terjadi karena kuatnya turbulensi sebagai akibat dari adanya interaksi yang kuat antara aliran massa air dengan topografi dasar perairan. Lapisan termoklin merupakan lapisan yang memiliki nilai difusivitas vertikal eddy yang tertinggi diikuti oleh lapisan dalam. Intensitas gelombang internal yang berinteraksi dengan topografi dasar perairan diduga sebagai pemicu utama tingginya nilai 
difusivitas vertikal eddy pada daerah sill sekitar Kepulauan Sangihe-Talaud.

\section{DAFTAR PUSTAKA}

Atmadipoera, A.S., Molcard, R., Madec, G., Wijffels, S., Sprintall, J., Koch Larrouy, A., Jaya I. \& Spangat A. 2009. Characteristics and variability of the Indonesian through flow water at the outflow straits. Deep Sea Research Part I: Oceanographic Research

Papers, 56:1942-1954.

Cisewski, B., Strass, V.H. \& Prandke, H. 2005. Upper-ocean vertical mixing in the Antarctic polar front zone. Deep Sea Research Part II: Topical Studies in Oceanography, 52:1087-1108.

Ffield, A. \& Gordon, A.L. 1992. Vertical mixing in the Indonesian thermocline. Journal of Physical Oceanography, 22:184-195. doi: 10.1175/1520-0485 022.

Ffield, A. \& Gordon, A.L. 1994. Vertical mixing in the Indonesian thermocline. Journal of Physical Oceanography, 22:184-195.

Hatayama, T. 2004. Transformation of the Indonesian throughflow water by vertical mixing and it relation to tidal generated internal wave. Journal of Oceanography, 60:569-585.

Hermansyah, H., Nugroho, D., Atmadipoera, A.S., Prartono, T., Jaya, I. \& Syamsudin, F. 2018. Disipasi Energi Kinetik Pasang Surut Barotropik dan Baroklinik di Laut Sulawesi. Jurnal Ilmu dan Teknologi Kelautan Tropis, 10(2):365-380. doi: 10.29244/jitkt.v10i2.21 664

Hermansyah, Atmadipoera, A.S., Prartono, T., Jaya, I. \& Syamsudin, F. 2019. Journal of Physics: Conference Series, 1341 (2019) 082001. doi: 10.1088/1742-6596/1341/8/ 082001

Koch-Larrouy, A., Madec, G., BouruetAubertot, P. \& Gerkema, T. 2007. Onthe transformation of Pacific Waterinto Indonesian Throughflow water by internal tidal mixing. Geophysical Research Letters, 34:1-6.

Finnigan, T.D., Luther, D.S. \& Lukas. 2002. Observation of enhanced diapycnal mixing near the Hawaiian Ridge. Journal of Physical Oceanography, 32:2988-3002.

Galbraith, P.S. \& Kelley, E. 1996. Identifying overturn in CTD profiles. Journal of
Atmospheric and Oceanic Technology, 13:688-702.

Jackson, C. 2007. Internal wave detection using the Moderate Resolution Imaging Spectroradiometer (MODIS). Journal of Geophysical Research: Oceans, 112: C11012. doi: 10.1029/2007JC004220.

Kara, A.B., Rochford, P.A. \& Hurlburt, H.E. 2000. An optimal definition for ocean mixed layer depth. Journal of Geophysical Research: Oceans, 105:16803-16821.

Koch-Larrouy, A., Madec, G., BouruetAubertot, P., Gerkema, T., Bessières, L. \& Molcard R. 2007. On the transformation of Pacific Water into Indonesian throughflow water by internal tidal mixing. Geophysical Research Letters, 34: L04604. doi:10.1029/2006GL028405

Lane-Serff, G.F. 2004. Topographic and boundary effects on steady and unsteady flow through straits. Topical Studies in Oceanography. Deep Sea Research Part II: Topical Studies in Oceanography, 51:321-334.

Law, C.S., Abraham, E.R., Watson, A.J. \& Liddicoat, M.I. 2003. Vertical eddy diffusion and nutrient supply to the surface mixed layer of the Antarctic Circumpolar Current. Journal of Geophysical Research: Oceans, 108(C8): 1-14.

Lorbacher, K., Dommenget, D., Niiler, P.P. \& Kohl A. 2005. Ocean Mixed Layer Depth: a Subsurface Proxy of OceanAtmosphere Variability. San Diago, California United State (US): The ECCO Report Series.

Li, X., Clemente-Colon, P. \& Friedman, K.S. 2000. Estimating oceanic mixed-layer depth from internal wave evolution observed from radarsat-1 SAR. Johns Hopkins APL technical digest, 21(1):130135.

Nagai, T. \& Hibiya, T. 2015. Internal tides and associated vertical mixing in the Indonesian Archipelago. Journal of Geophysical Research: Oceans, 120(5):3373-3390.

Polzin, K.L., Toole, J.M., Ledwell, J.R. \& Schmitt, R.W. 1997. Spatial variability of turbulent mixing in the Abyssal Ocean. Science. 276:93-96.

Pond, S. \& Pickard, G.L. 1983. Introductory Dynamical Oceanography. Ed ke-2. 
Oxford, United Kingdom (GBR): Pergamon Press.

Purwandana, A., Atmadipoera, A.S. \& Purba, M. 2014. Distribusi Percampuran Turbulen di Perairan Selat Alor. IImu Kelautan: Indonesian Journal of Marine Sciences, 19(1):43-54. doi: 10.14710/ik.jims.19.1.43-54
Robertson, R. \& FfieldA. 2005. M2 baroclinic tides in the Indonesian Seas. Journal of Oceanography, 18:62-73.

Suteja, Y., Purba, M. \& Atmadipoera, A.S. 2015. Percampuran Turbulen Di Selat Ombai. Jurnal IImu dan Teknologi Kelautan Tropis, 7:71-82. 